\title{
ST PAUL ON SOUL, SPIRIT AND THE INNER MAN
}

\author{
George H. van Kooten*
}

\section{Introduction}

In this paper I shall address the issue of whether St Paul had a Jewish or a Greek understanding of the human soul, regardless of his views on the status of the body. ${ }^{1}$ I shall argue that, despite some distinctively Jewish features-which Paul shares with his contemporary fellow-Jews Philo of Alexandria and Flavius Josephus-, his conceptuality of the soul is basically Greek, even to a greater extent than is commonly thought.

Until the present day, many biblical scholars continue to emphasize the distinctively Jewish or distinctively Pauline aspects of Paul's psychology and anthropology. To demonstrate the Jewish essence of his psychology, they point to the preponderance of allegedly Semitic concepts such as heart ( $\kappa \alpha \rho \delta i \alpha)$ and flesh ( $\sigma \alpha \alpha \beta)$, often choosing to ignore the more 'noetic' language (e.g. vov̂s) which Paul also employs. ${ }^{2}$ Similarly, they call attention to the Semitic expressions which have left their mark on the Greek translation of the Jewish bible, the Septuagint: the so-called Septuagintisms. Paul's use of the very word $\psi v x \eta$, for instance, can be reduced to a mere Septuagintism if one focuses on such expressions as 'every soul' ( $\pi \hat{\alpha} \sigma \alpha \psi v \chi \eta)$ ) which only function, it is

* University of Groningen.

${ }^{1}$ I wish to thank the participants in the seminar for their useful and stimulating suggestions and criticism, and in particular Prof. John Dillon. Sections 3-4 were first read at the 136th Annual Meeting of the American Philological Association in Boston, January 2005 (session 'Neoplatonism and Living the Good Life'), and likewise profited much from discussion. I am grateful also to Dr Robbert M. van den Berg (Leiden) for his careful comments on an earlier draft and to Dr Maria Sherwood-Smith for correcting the English in this paper. The present paper has now been incorporated into G. H. van Kooten, Paul's Anthropology in Context: The Image of God, Assimilation to God, and Tripartite Man in Ancient Judaism, Ancient Philosophy and Early Christianity (Wissenschaftliche Untersuchungen zum Neuen Testament 232), (Tübingen, 2008), esp. into chap. 5.2.1, pp. 298-302, and chap. 7.2.3, pp. 370-374.

2 See, e.g., U. Schnelle, The Human Condition: Anthropology in the Teachings of Jesus, Paul, and John (trans. by O. C. Dean, Jr), (Edinburgh, 1996) (trans. of Neutestamentliche Anthropologie: Jesus-Paulus-Johannes [Biblisch-theologische Studien 18], NeukirchenVluyn, 1991), chap. 3 on Pauline anthropology, esp. chap. 3.7, pp. 59-63 on бóp $\xi$ and

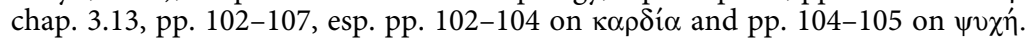

(C) GEORGE H. VAN KOOTEN, 2009 | DOI:10.1163/9789047429678_004

This is an open access chapter distributed under the terms of the CC BY-NC-ND 4.o license. 
supposed, as a Semitic way of referring to each individual person. And to highlight the distinctiveness of Paul's own thoughts about the human soul, distinct from both Jewish and Greek thought, they highlight the antitheses which Paul forges between spirit $(\pi v \varepsilon \hat{\mu} \mu \alpha)$ and flesh ( $\sigma \alpha ́ \rho \xi)$, for instance, and between spirit $(\pi v \varepsilon \hat{\mu} \mu \alpha)$ and body $(\sigma \hat{\omega} \mu \alpha)$.

My own position is that one should not be too quick to assume that Paul uses distinctively Jewish-Semitic concepts when writing Greek. Although $\sigma \alpha \dot{\alpha} \xi \xi$ is an important concept in the Jewish scripture, in nonJewish Greek, too, it can denote the flesh as the seat of the affections and lusts, the fleshly nature, ${ }^{3}$ or man in his vulnerability (LSJ 1585 $\sigma \alpha \dot{\alpha} \rho \xi$ II.1). The word is employed in this sense by Philo in a passage which otherwise develops a genuinely Greek psychology, as we shall see shortly. Seen in this light, there is nothing distinctively Jewish about Paul's use of $\sigma \alpha \dot{\alpha} \rho \xi$, nor anything specifically Pauline about his antithesis between $\sigma \alpha ́ \rho \xi$ and $\pi v \varepsilon \hat{\jmath} \mu \alpha$.

If this is true of the concept of flesh, the same applies to Paul's use of the term $\psi v \chi \eta$. I will start with a discussion of the latter in $\$ 1$, before focusing on the triadic expression $\pi v \varepsilon \hat{\mu} \mu \alpha, \psi v \chi \eta \dot{\eta}$, and $\sigma \hat{\omega} \mu \alpha$ in $\$ 2$ and moving to the broader context of Paul's psychology, which is consistent with a Greek understanding of $\psi v \chi \eta$, in $\$ \$ 3-4$. In my discussion I hope to do justice both to Paul's Jewish colouring of his discourse of the soul, and to his own theological emphasis. Neither the Jewish nor the Pauline angle to this discourse should come as a surprise, as normally every thinker contextualizes 'general' topics within his or her own train of thought. In essence, however, Paul's discussion of the soul is inseparable from its larger setting in the Graeco-Roman period.

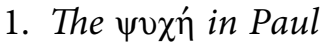

There are certainly some instances of Septuagintisms in Paul's use of

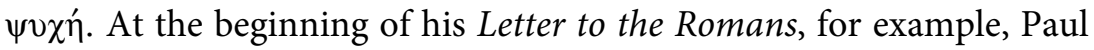
warns both Greek and Jews:

for those who are self-seeking and who obey not the truth but wickedness, there will be wrath and fury. There will be anguish and distress for

${ }^{3}$ H. G. Liddell, R. Scott \& H. S. Jones, A Greek-English Lexicon, (Oxford, 1996) (= LSJ), 1585 s.v. $\sigma \alpha ́ \rho \xi$ II.1. 


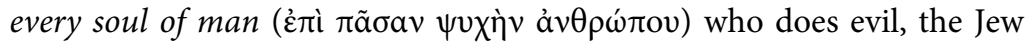
first and also the Greek (Rom 2.8-9 NRSV). ${ }^{4}$

The expression 'every soul of man' occurs only in the Septuagint (Numbers 19.11; Isaiah 13.7) and not in any other extant Greek literature. ${ }^{5}$ In a periphrastic way, it refers to every individual human being, 'everyone'. Yet, one should not overemphasize the Semitic background of this Septuagintism, since in non-Jewish Greek, too, similar periphrastic descriptions of individual human beings do exist. Plato, for instance, in his Laws, speaks of 'every soul of all citizens' ( $\pi \hat{\alpha} \sigma \alpha$

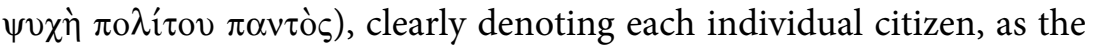
context makes clear:

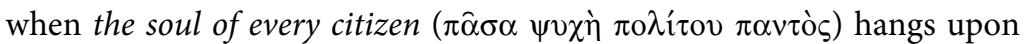
this [i.e. upon his own private property], it is incapable of attending to matters other than daily gain. Whatsoever science or pursuit leads to this, every man individually (i $i \delta i \alpha \underline{\alpha} \hat{\alpha})$ ) is most ready to learn and to practise; but all else he laughs to scorn (Laws 831C).

The resemblance between Paul's use of $\psi v \chi \eta$ and general Greek usage is even closer when Paul just speaks about 'each soul' ( $\pi \hat{\alpha} \sigma \alpha \psi v \chi \eta)$ ), without further qualification, in Rom 13.1; there are many parallels in the Septuagint, but at the same time the phrase frequently occurs in non-Jewish Greek literature, especially in Plato and Aristotle and in literature dependent upon them, and not always in a strictly technical sense. This should warn us against stressing the Semitic background of Paul's alleged Septuagintisms too much. At the very least, it is clear that these Septuagintisms were not incomprehensible in a non-Jewish Greek context and, more importantly, did not preclude Paul from developing a Greek understanding of the soul, as I hope to demonstrate.

There are some peculiar Septuagintisms, but their number is limited indeed. The most important example consists of a Septuagint quotation

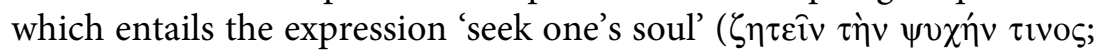
Rom 11.3 quoting 1 Kings 19.10 LXX), which in the Septuagint stands for the intention of murdering someone. This particular meaning seems

\footnotetext{
${ }^{4}$ Translations from the Bible are normally taken from the New Revised Standard Version, with small alterations where necessary, and those from Classical authors are normally derived from the Loeb Classical Library, again with occasional changes.

${ }^{5}$ Observations with regard to the occurrence of particular linguistic terms in this section are based on consultation of the Online Thesaurus Linguae Graecae Digital Library $\left(\mathrm{TLG}^{\circledast}\right)$.
} 
to be absent from Classical Greek, where it means rather the opposite (see, e.g., Plato, Phaedrus 252E: 'The followers of Zeus desire the soul

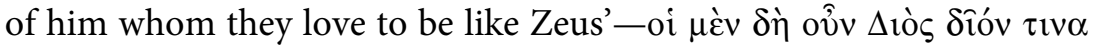

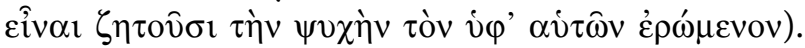

An interesting case is the expression 'risking one's soul' in Paul's

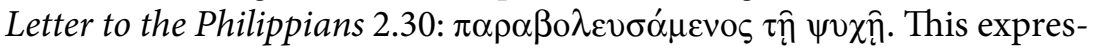
sion is not common in Greek, but is not found in the Septuagint either, so that its meaning seems rather to be dependent on the context, and to be a Pauline adaptation of the phrase's general Greek meaning of 'exposing oneself in one's soul', i.e. risking one's life.

Further instances of $\psi v \chi \eta^{\prime}$ in Paul can also be understood in the word's Greek meaning of $\psi v \chi \eta$ as 'life' (LSJ $2026 \psi v \vee \chi$ I) or 'the conscious self or personality as centre of emotions, desires, and affections'

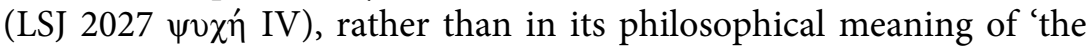

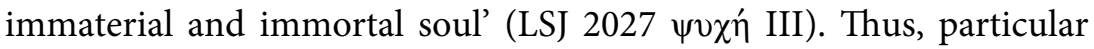
fellow-workers of Paul's are said to have risked their own necks 'for my

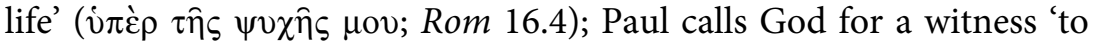

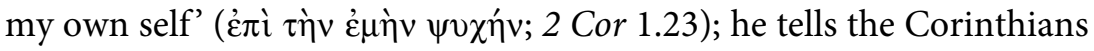
that he will gladly spend and be spent 'for your lives' (i $i \grave{\varepsilon} \rho \tau \hat{\omega} v \psi v \chi \hat{\omega} v$ v $\mu \hat{\omega} v ; 2$ Cor 12.15) and, as he and his co-authors tell the Thessalonians,

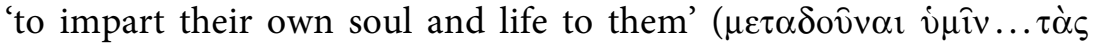
$\dot{\varepsilon} \alpha v \tau \hat{\omega} v \psi v \chi \chi \alpha$ s; 1 Thess 2.8).

In short, one should allow the possibility that various Greek meanings of $\psi v \times y^{\prime}$ are present in Paul, including non-technical ones, rather than concluding that Paul employs this terminology in Septuagintist or idiosyncratic ways.

Paul also uses common Greek expressions which contain the word $\psi v \chi \eta$ ' or some cognate terms when he talks about (a) 'striving with

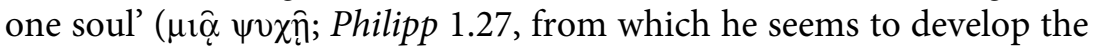

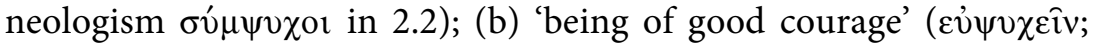
Philipp 2.19); (c) 'being of equal spirit, of like soul or mind' (iбó $\psi v \chi o$; Philipp 2.20); or about (d) $\tau \grave{\alpha} \not \alpha \psi v \chi \alpha$, the soulless, lifeless, material things (1 Cor 14.7), a term which, in the Septuagint, occurs only once in The Wisdom of Solomon (13.17; 14.29), a writing from the Hellenistic period. Later Pauline writings also speak of working, or of doing the will

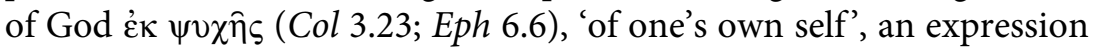
which does not occur only in the Septuagint but is abundant in Greek literature. In 'Semiticizing' translations of these writings, this expression is wrongly translated as 'from the heart' or 'heartily'. 
If we review all the $\psi v \chi$-passages in Paul, there are only a few examples of terms which are limited to the Septuagint and its subsequent Christian

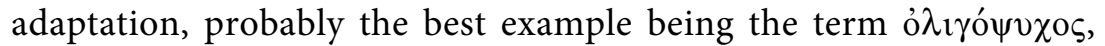
faint-hearted or feeble-minded; this occurs in the Septuagint and is predominantly used in the Christian tradition and hardly at all in pagan Greek literature. Paul uses it in his exhortation to 'encourage the fainthearted, support the weak, and be patient toward all' (1 Thess 5.14). These exceptions only serve to emphasize our findings that, as a rule, Paul's use of the term $\psi v \vee$ y reflects its broad application in Greek.

Paul is less idiosyncratic than is often assumed, as will become particularly clear from a few $\psi v \chi$-passages which will be discussed now. Although we shall see in these instances that the language is indeed coloured by specific Pauline and Jewish concerns and predilections, they also show that these are merely shades and tints in an otherwise Greek picture of man. In his discussion of the future resurrection of the body in 1 Cor 15, for example, Paul argues that the future human

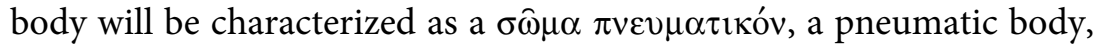
whereas the present body, which will be buried, is a 'psychical body',

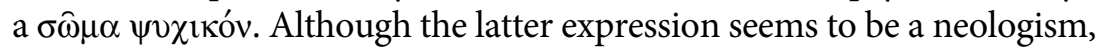
forged by Paul, the former expression, $\sigma \hat{\omega} \mu \alpha \pi v \varepsilon v \mu \alpha \tau \iota \kappa o ́ v$, is a term which is applied in Stoicism to characterize the abiding nature of God. Whereas God, insofar as he is material, is perishable and liable and subject to change, as becomes clear in the process of conflagration, the authoritative part of God's soul ( $\tau$ ò i $\gamma \varepsilon \mu o v ı$ òv), the governing part of the universe, is a $\sigma \hat{\omega} \mu \alpha \pi v \varepsilon v \mu \alpha \tau$ เóv, a pneumatic and ether-like body (SVF 1054; = Origen, Commentary on John 13.21.128). As Origen puts it: the Stoics 'are not ashamed to say that since God is a body he is also subject to corruption, but they say his body is pneumatic and like ether,

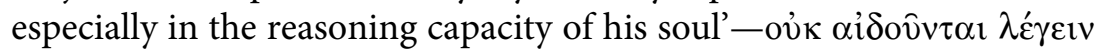

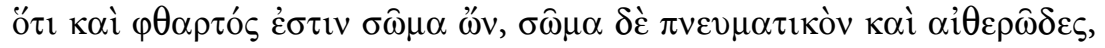

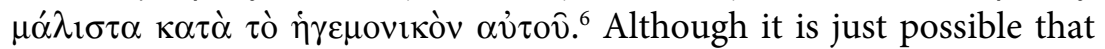
the terminology of $\sigma \hat{\omega} \mu \alpha \pi v \varepsilon v \mu \alpha \tau 1 \kappa o ́ v$ is due to Origen, who preserved this passage, I regard it as an authentic Greek expression, as it is also

${ }^{6}$ Trans.: R. E. Heine, Origen: Commentary on the Gospel according to John, vol. 2: Books 13-32 (The Fathers of the Church 89), (Washington, D.C., 1993, 94, with a small alteration.) 
attested elsewhere. ${ }^{7}$ Paul regards this term as suitable to express the specific corporeality of the future, post-resurrection body.

This Stoic term is now placed in antithesis to $\sigma \omega \hat{\omega} \mu \alpha \psi v \chi 1 \kappa o ́ v$, which combination Paul seems to have constructed himself. It is still possible to see where he derived his inspiration from, as his antithesis is followed by a quotation from Gen 2.7 LXX: 'So also it is written: "The first

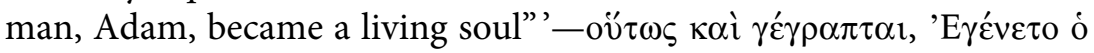

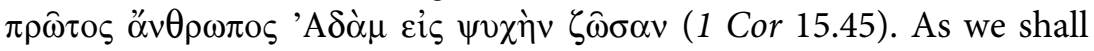
see shortly, this text was also interpreted by fellow-Jews such as Philo and Josephus as a passage about the human soul. The contrast between a $\sigma \hat{\omega} \mu \alpha \pi v \varepsilon v \mu \alpha \tau \imath \kappa o ́ v$ and a $\sigma \hat{\omega} \mu \alpha \psi \alpha v \chi$ เóv is developed by Paul to differentiate between (a) a life which is so dominated by the $\pi v \varepsilon \hat{\nu} \mu \alpha$ that even the body becomes spiritual, and (b) a life dominated by the $\psi v \chi \eta^{\prime}$, which is the entity-as we shall see in the next section-in the middle between body and spirit.

In the context of his discussion about the corporeality of the resurrection in 1 Cor 15, Paul understandably focuses on the $\sigma \omega \hat{\omega} \mu \alpha$ and distinguishes between a pneumatic body and a psychic body. But the implied antithesis between $\pi v \varepsilon \hat{v} \mu \alpha$ and $\psi v \chi \eta \dot{\eta}$, which now manifests itself at the level of adjectives qualifying the sort of body involved, already comes to the fore in 1 Cor 2 where, already in the present life, Paul distinguishes between two groups: on the one hand, there are

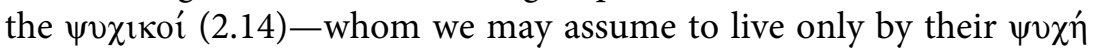

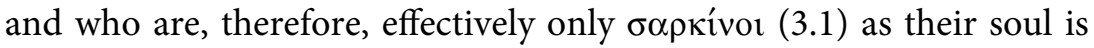
lacking any guiding principle and gives in to the flesh; on the other hand, there are the $\pi v \varepsilon v \mu \alpha \tau \imath$ коí $(2.15 ; 3.1$; cf. Gal 6.1), who are able to receive and inquire into the things of God's $\pi v \varepsilon v \hat{\mu \alpha}$ and possess the 'mind (vov̧ $\varsigma$ ) of Christ' (2.16).

\section{The Trichotomy Between $\pi v \varepsilon \hat{v} \mu \alpha, \psi v \chi \eta$, and $\sigma \hat{\omega} \mu \alpha$}

This differentiation between $\pi v \varepsilon v \hat{\mu \alpha}$ and $\psi v \chi \eta \dot{~ i s, ~ I ~ b e l i e v e, ~ a l r e a d y ~}$ expressed in Paul's First Letter to the Thessalonians, where Paul exhorts his readers to preserve their entire $\pi v \varepsilon \hat{\nu} \mu \alpha, \psi v \chi \eta$, and $\sigma \hat{\omega} \mu \alpha$ so that they

\footnotetext{
${ }^{7}$ Comarius (1st cent. AD?), De lapide philosophorum 2.290; cf. also Zosimus (3rd/4th

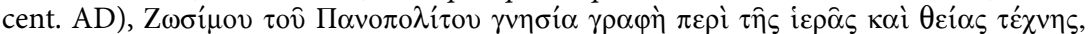

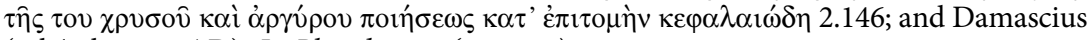
(5th/6th cent. AD), In Phaedonem (versio 1) 551.
} 
may remain sound and perfect (5.23). ${ }^{8}$ As I shall argue, this trichotomy seems to be the Jewish adaptation of the general Greek distinction between vovิ $\varsigma, \psi v \chi \dot{\eta}$, and $\sigma \hat{\omega} \mu \alpha$, which we find also in Greek philosophers contemporary with Paul, such as Plutarch. ${ }^{9}$ As we have just seen at the end of $\$ 1$, within 1 Cor 2.14-16 Paul's wording switches easily from terms with $\pi v \varepsilon \hat{v} \mu \alpha$ to the term vov̂s; they seem to be synonymous. I shall first demonstrate that in Jewish authors such as Philo and Josephus $\pi v \varepsilon v \mu \alpha$ is distinguished from $\psi v \chi \eta$, and subsequently that, in Philo, the trichotomy between $\pi v \varepsilon \hat{v} \mu \alpha, \psi v \chi \eta$, and $\sigma \hat{\omega} \mu \alpha$ occurs alongside the differentiation between vovิธ, $\psi v \chi \eta^{\prime}$, and $\sigma \hat{\omega} \mu \alpha$. Finally, it will be shown, in $\$ \$ 3-4$, that the trichotomy Paul mentions in 1 Thess is in line with his broader anthropological reflections, especially his views on God's image, the inner man, and the human vovs.

In Philo, the distinction between $\pi v \varepsilon \hat{\nu} \mu \alpha$ and $\psi v \chi \eta \dot{~ i s ~ m a d e ~ c l e a r l y ~}$ in his treatise Quis rerum divinarum heres 55-57. Because this entire passage is crucial, I give it first, signalling the relevant Greek key-terms between brackets:

We use 'soul' ( $\psi v \chi \eta ்)$ in two senses, both for the whole soul ("丷 $\tau \varepsilon$ ö $\lambda \eta$ ) and also for its dominant part ( $\tau$ ò $\dot{\gamma} \gamma \mu$ ovıкòv), which properly speaking is the soul's soul ( $\psi v \chi \grave{\eta} \psi v \chi \eta \hat{\eta} \varsigma)$... And therefore the lawgiver held that the substance of the soul is twofold, blood being that of the soul as a whole, and the divine breath or spirit $(\pi v \varepsilon \hat{v} \mu \alpha)$ that of its most dominant part.

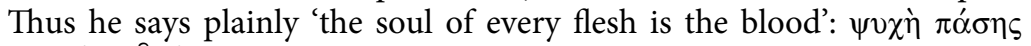

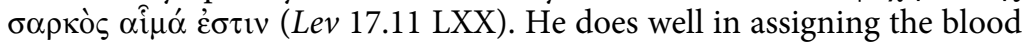
with its flowing stream to the riot of the manifold flesh ( $\sigma \alpha \alpha \rho \xi)$, for each is akin to the other. On the other hand he did not make the substance of the mind (vovs) depend on anything created, but represented it as breathed upon by God ( all, he says, "blew into his face the breath of life, and man became a liv-

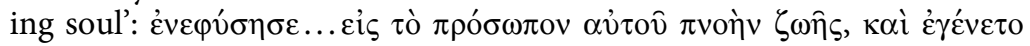

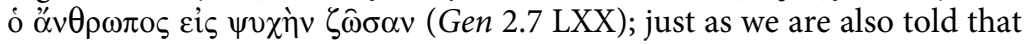

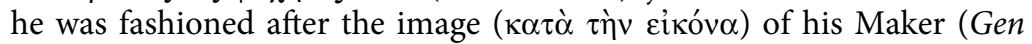
1.27 LXX). So we have two kinds of men, one that of those who live by

${ }^{8}$ Cf. A. J. Festugière, L'idéal religieux des grecs et l'évangile (Études bibliques), 2nd ed. (Paris, 1932), Appendix B: 'La division corps-âme-ésprit de 1 Thessal. 5.23 et la philosophie grecque', pp. 196-220. For a detailed discussion of the trichotomy of $\pi v \varepsilon \hat{v} \mu \alpha$, $\psi v \chi \eta$, and $\sigma \omega \hat{\omega} \mu \alpha$ in Philo and Paul, see van Kooten, Paul's Anthropology in Context, chap. 5: 'The Two Types of Man in Philo and Paul: The Anthropological Trichotomy of Spirit, Soul and Body', pp. 269-312.

9 On the Greek philosophical trichotomy, see J. Dillon, 'Plutarch and the Separable Intellect', in: A. Pérez Jiménez \& F. Casadesús (eds), Estudios sobre Plutarco: Misticismo y Religiones Mistéricas en la Obra de Plutarco, (Madrid-Málaga, 2001), pp. 35-44. 


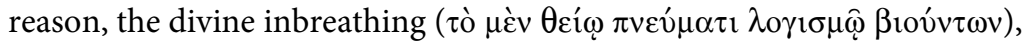
the other of those who live by blood and the pleasure of the flesh ( $\tau$ ò $\delta \grave{\varepsilon}$

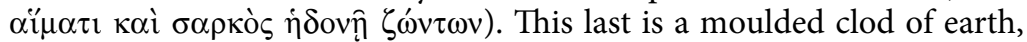
the other is the faithful impress of the divine image (Quis rerum divinarum heres 55-57).

In this passage, Philo distinguishes the $\psi v \chi \eta$ from the soul proper, the

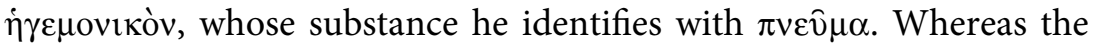
soul, in the broad sense, is associated with the flesh ( $\sigma \alpha \dot{\rho} \rho \xi)$ and with

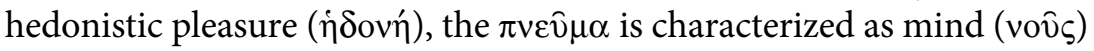
and as an impress of the divine image, and is regarded as the direct result of God's breathing upon man. Even though the Septuagint text of Gen 2.7 does not state this explicitly, God's $\pi v \varepsilon \hat{\nu} \mu \alpha$ is taken to be

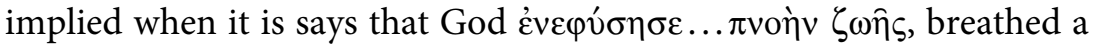
breath of life. In passing, I briefly note that Philo's antithesis between $\pi v \varepsilon \hat{v} \mu \alpha$ and $\sigma \alpha \dot{\rho} \xi$ resembles, or is in fact identical with, Paul's. The most important observation, however, is that Philo's antithesis between $\pi v \varepsilon \hat{v} \mu \alpha$ and $\psi v \chi \eta$ is made on the basis of Gen 2.7, in which it is thought to be implied.

Elsewhere, too, Philo emphasizes this contrast between $\pi v \varepsilon v \hat{\mu \alpha}$ and $\psi v \chi \eta$ on the basis of Gen 2.7 (Quod deterius potiori insidiari soleat $80-84)$. As in the previous passage, Philo sets out to reconcile two contradictory anthropological statements in the Pentateuch, one asserting that 'the life ( $\psi v \chi \eta$ ') of all flesh is the blood' (Lev 17.11), the other, that God 'breathed into his face the breath of life, and man became a living

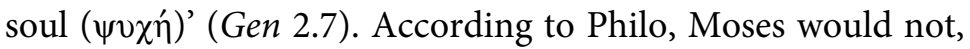

having already said that the essence of life ( $\left.\psi v \chi \eta^{\prime}\right)$ is $\pi v \varepsilon v \mu \alpha$ (Gen 2.7 LXX), have said further on that it is some different substance, namely blood (Lev 17.11 LXX), had he not been bringing the matter under some most vital and essential principle. (...) Each of us (...) is two in number, an animal and a man. To either of these has been allotted an inner power akin to the qualities of their respective life-principles, to one the power of vitality, in virtue of which we are alive, to the other the power of reasoning, in virtue of which we are reasoning beings. Of the power of vitality the irrational creatures partake with us; of the power of reasoning God is, not indeed partaker, but originator, being the fountain of archetypal reason. To the faculty which we have in common with the irrational creatures blood has been given as its essence; but to the faculty which streams forth from the fountain of reason $\pi v \varepsilon v \hat{\mu} \alpha$ has been assigned (...). This is why he says that the blood is the life ( $\left.\psi v \chi \eta^{\prime}\right)$ of the flesh, being aware that the fleshly nature has received no share of mind (vovs), but partakes of vitality just as the whole of our body $(\sigma \hat{\omega} \mu \alpha)$ does; but man's life ( $\psi v \chi \eta \dot{n})$ 
he names $\pi v \varepsilon v \hat{\mu} \alpha$, giving the title of 'man' not to the composite mass (...), but to that God-like creation with which we reason (Quod deterius potiori insidiari soleat 81-84).

The distinction between $\pi v \varepsilon v \hat{\mu} \alpha$ and $\psi v \chi \eta$ is not only applied in the narrative of the creation of man, but also in narratives about virtuous men such as Abraham: 'the divine spirit $(\pi v \varepsilon \hat{v} \mu \alpha)$ which was breathed upon him ( $\kappa \alpha \tau \alpha \pi v \varepsilon v \sigma \theta \varepsilon$ ć) from on high made its lodging in his soul ( $\psi v \chi \eta)$, and invested his body $(\sigma \hat{\omega} \mu \alpha)$ with singular beauty' (De virtutibus 217). This shows that the distinction between $\pi v \varepsilon \hat{v} \mu \alpha, \psi v \chi \eta$, and $\sigma \hat{\omega} \mu \alpha$ is considered to be of ongoing relevance.

Josephus also interprets Gen 2.7 in terms of the dichotomy of $\pi v \varepsilon \hat{\mu} \mu \alpha$ and $\psi v \chi \eta$ r. In the retelling of the Pentateuch in his Jewish Antiquities, Josephus even explicitly inserts the term $\pi v \varepsilon \hat{\mu} \mu \alpha$ in his alleged quotation of Gen 2.7: 'Moses begins to interpret nature, writing on the formation of man in these terms: "God fashioned man by taking dust from the earth and instilled into him $\pi v \varepsilon v \hat{\mu \alpha}$ and $\psi v \chi \eta$ '." Now this man was called Adam' (1.34; cf. 3.260).

Against this background of Jewish-Hellenistic interpretations of Gen 2.7, it becomes clear that Paul, in distinguishing between $\pi v \varepsilon \hat{v} \mu \alpha, \psi v \chi \eta$, and $\sigma \hat{\omega} \mu \alpha$ in 1 Thess 5.23, is following Jewish practice, as attested in Philo and Josephus. Yet, at the same time, Philo renders it clear that this trichotomy is simply the Jewish adaptation of the general Greek differentiation between vovิs, $\psi v \chi \eta$, and $\sigma \hat{\omega} \mu \alpha$. As I shall now show, in Philo's writings many passages indicate that he uses both trichotomies and equates the God-inbreathed human spirit $(\pi v \varepsilon \hat{v} \mu \alpha)$ with the mind (vôิธ).

According to Philo, the vov̧ is the ruler of the entire $\psi v \chi \eta^{\prime}$ (De opificio mundi 30); it is the sovereign element of the $\psi v \chi \eta$ ' (69); 'what the vov̂s is in the $\psi v \chi \eta^{\prime}$, this the eye is in the body; for each of them sees,

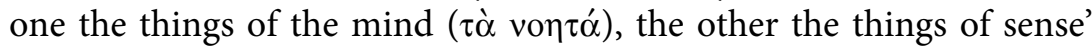
(53). Or, using a different metaphor, the vov $\varsigma$ is said to be 'the ruler of the flock, taking the flock of the $\psi v \chi \chi^{\prime}$ in hand' (De agricultura 66). As he describes it clearly in Legum allegoriarum 1.39:

the vovิ (is) the dominant element of the $\psi v \chi \eta$ : into this only does God breathe, whereas He does not see fit to do so with the other parts (...); for these are secondary in capacity. By what, then were these also inspired? By the vov $\varsigma$, evidently. For the vov $\varsigma$ imparts to the portion of the $\psi v \chi \eta^{\prime}$ that is devoid of reason a share of that which it has received from God, so that the vov̧ was be-souled by God, but the unreasoning part by the 
vovิs. For the vov̂s is, so to speak, God of the unreasoning part. (...) The vov̧ $s$ that was made after the image and original might be said to partake of $\pi v \varepsilon v \hat{\mu \alpha}$ (Legum allegoriarum 1.39).

It is 'the wholly purified vov̂ which disregards not only the $\sigma \hat{\omega} \mu \alpha$, but that other section of the $\psi v \chi \eta$ which is devoid of reason and steeped in blood, aflame with seething passions and burning lusts' (Quis rerum divinarum heres sit 64). This differentiation between vôิ, , $\psi \chi \chi \eta$, and $\sigma \hat{\omega} \mu \alpha$ also clearly comes to the fore when the wise man is called the

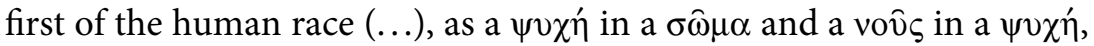
or once more heaven in the world or God in heaven' (De Abrahamo 272).

These examples will suffice to show that in Philo both trichotomies occur, the triad $\pi v \varepsilon \hat{v} \mu \alpha, \psi v \chi \eta$, and $\sigma \hat{\omega} \mu \alpha$ as well as the triad vov̂s, $\psi v \chi \eta$, and $\sigma \hat{\omega} \mu \alpha$, and that in fact the former is the specifically Jewish adaptation (inspired by Gen 2.7 LXX) of the latter, general ancient philosophical trichotomy. I shall not discuss the Greek background of the differentiation between vovิs, $\psi v \chi \eta \dot{\eta}$, and $\sigma \hat{\omega} \mu \alpha$ any further here. The point I want to emphasize now is that Paul clearly resembles Philo and Josephus in distinguishing between $\pi v \varepsilon \hat{v} \mu \alpha, \psi v \chi \eta \dot{\eta}$, and $\sigma \hat{\omega} \mu \alpha$, and that he, too, will have understood this in a Greek way.

My analysis differs notably from the interpretation of 1 Thess 5.23 offered in one of the most recent, rare comprehensive treatments of Paul's anthropology, that of Udo Schnelle:

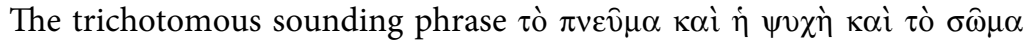
reflects no Hellenistic anthropology according to which a person is divided into body, soul, and spirit. Paul is merely emphasizing that the sanctifying work of God concerns the whole person. This interpretation is suggested (...) by the observation that in 1 Thessalonians $\pi v \varepsilon v \hat{\mu} \alpha$ is for Paul not a component of the human essence but the expression and sign of the new creative activity of God in humankind. With $\psi v \chi \eta \dot{~ a n d ~} \sigma \hat{\omega} \mu \alpha$ Paul is only adding what constitutes each person as an individual. What is actually new and determinative is the Spirit of God. With his use of

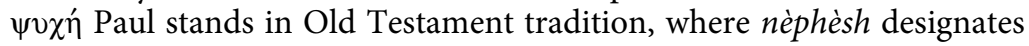
the whole person. ${ }^{10}$

This interpretation ignores the similarities between Paul and his contemporaries Philo and Josephus, who show incontrovertibly that they are acquainted with trichotomous Hellenistic anthropology.

\footnotetext{
${ }^{10}$ Schnelle, The Human Condition, pp. 104-5 (italics mine).
} 
As further support of my interpretation of Paul, I wish to point to the broader context of his anthropology, in which terms such as metamorphosis into God's image and within one's vov̂s, and the notion of

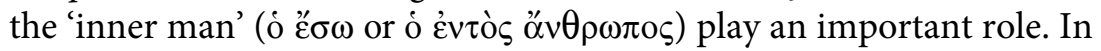
Paul, the 'inner man' (2 Cor 4.16; Rom 7.22) is synonymous with the vovิ (Rom 12.2), which-as in Philo-is in turn identical with the Jewish notion of the God-inbreathed human $\pi v \varepsilon v \hat{\nu} \alpha .{ }^{11}$ I shall now demonstrate the importance of such anthropological notions in Paul's Corinthian correspondence (\$3) and in his Letter to the Romans (\$4).

\section{Paul's Second Letter to the Corinthians (2 Cor)}

Paul's 2 Cor has been transmitted as a composite letter; the part I am currently interested in runs from 2 Cor 2.14 to 7.4 and constitutes a clearly distinguishable text fragment within 2 Cor. It is clear from the outset that Paul is involved in a philosophical discussion with his Corinthian public. According to Paul, he himself is intent on spreading the knowledge of God throughout the Eastern Mediterranean (2.14), but he flatly denies that his working methods are comparable with the

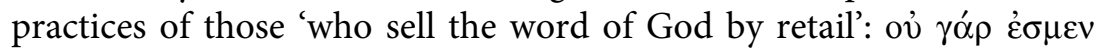

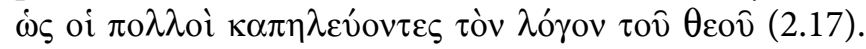

Paul's language clearly echoes the warnings of Socrates in Plato's Protagoras against buying knowledge from the sophist Protagoras. Socrates urges Hippocrates:

we must see that the sophist in commending his wares does not deceive us, like the wholesaler and the retailer who deal in food for the body. (...) So too those who take the various subjects of knowledge from city

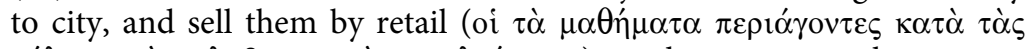

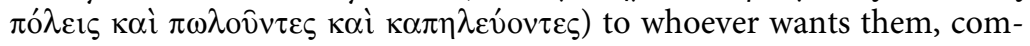
mend everything that they have for sale (Protagoras 313D-E).

In his letter, Paul has to face accusations that he himself behaves like itinerant sophists who demand money for their instruction, though he falls short of their standards of rhetoric and performance.

As Bruce Winter has shown, in his Corinthian community Paul is confronted with a sophistic movement among Jewish Christians, who

${ }^{11}$ For $\pi v \varepsilon \hat{\mu} \mu \alpha$, see 1 Cor 2.11 ; for vovิ , see 1 Cor 1.10 ; 14.14-15, 14.19. 
are critical of Paul as orator and debater. ${ }^{12}$ Apparently, Paul deliberately distances himself from the sophist movement by drawing on Platonic criticism of the sophists and characterizing their activity as $\kappa \alpha \pi \eta \lambda \varepsilon v \varepsilon_{\varepsilon v v}$. This shows that the setting of Paul's text under discussion is philosophical from the very beginning. He himself claims to speak not for financial gain, but with sincerity ( $\left.\varepsilon^{i} \lambda \iota \kappa \rho v \varepsilon i ́ \alpha\right)$. Paul stresses that he is not interested in using letters of recommendation (3.1). Rather than using an outward, rhetorical modus operandi in communicating with his public, he is bent on their inner transformation. 'We all', Paul says, 'who, with uncovered faces, behold as in a mirror the glory of the Lord, are being transformed into the very one image': $\dot{\eta} \mu \varepsilon \hat{\imath} \varsigma \delta \grave{\varepsilon}$

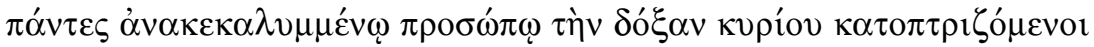

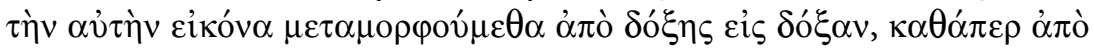

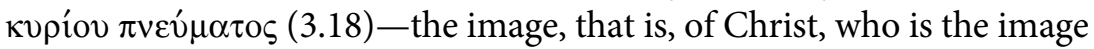

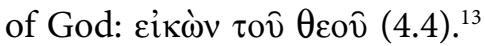

Soon Paul underpins this line of thought by drawing on the notion of the 'inner man', and it is there that the closest parallels between Paul and Platonist philosophers are found. According to Paul, rather than being occupied with shallow rhetoric, man should experience metamorphosis towards God, and acquire a new form within.

In a similar passage in his Letter to the Romans, Paul points out that this transformation takes place by renewing one's vov̂s, one's mind:

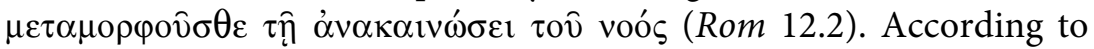

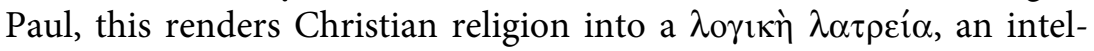
lectual, non-cultic, ethical worship of God (Rom 12.1-2). In 2 Cor, this transformation of one's mind is said to take place when it is modelled on God's image. The underlying thought is, of course, that by being transformed into God's image, man starts to partake of God himself.

Having pointed to the need to experience inner transformation, Paul concludes that, on account of this ontological change, and because of his involvement in spreading this message, he will not lose heart, despite

${ }_{12}$ B. W. Winter, Philo and Paul among the Sophists: Alexandrian and Corinthian Responses to a Julio-Claudian Movement, 2nd ed. (Grand Rapids, Michigan, 2002), esp. p. 91 and pp. 167-8 with reference to Plato, Protagoras 313. Whereas Winter focuses predominantly on 1 Cor $1-4$ and 2 Cor $10-13$, my exploration takes its starting point in 2 Cor 2.14-7.4 and, accepting Winter's reconstruction of Paul's critique of his sophistic opponents, deals less with this critique and more explicitly with Paul's alternative to sophism, i.e. with his view on the 'inner man' and man's transformation into God's image.

${ }^{13}$ Cf. van Kooten, Paul's Anthropology in Context, chap. 6, pp. 313-339. 
the controversy which he faces (4.1). He once again emphasizes that he does not disguise God's message (4.2), like the Jewish-Christian sophists, by selling the word of God by retail (2.17). He claims to reveal the truth and not to make use of letters of recommendation, recommending himself instead to the consciousness or conscience ( $\sigma v v \varepsilon i ́ \delta \eta \sigma 1 \varsigma)$ of all men (4.2) - quite the opposite of mere sophistic rhetorical strategies. Despite his circumstances, Paul indeed does not lose heart, since if the 'outer man' is destroyed, he says, 'the inner man ( $\dot{o}$ " $\left.\sigma \omega \alpha^{\prime} v \theta \rho \omega \pi \mathrm{o}\right)$ ) is renewed day by day' (4.16). Paul now uses the Platonic notion of the 'inner man' (Plato, Republic IX 589A-B) to support his line of thought. ${ }^{14}$

The same antithesis between the outer and inner man is present in Plotinus. My choosing to compare Paul with Plotinus, who flourished about two hundred years later, may be justified by the vast corpus of Plotinus' writings, which facilitates a careful analysis between philosophical-Platonic and Pauline anthropology. Of course, Plotinus himself contributed to the further development of Platonic thought, yet the significant terminological similarities between Paul and Plotinus must be due, in no small part, to a shared philosophical heritage. This heritage includes their extensive reflections on the Platonic 'inner man'. In Plotinus' view,

it is not the soul within ( $\dot{\eta} \ddot{\varepsilon} v \delta o v \psi v \chi \dot{\eta})$ but the outside shadow of man

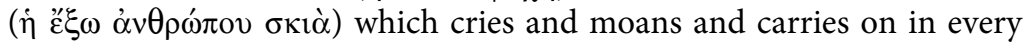
sort of way on a stage which is the whole earth where men have in many places set up their stages. Doings like these belong to a man who knows

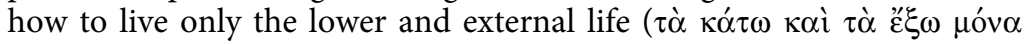

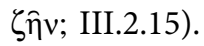

'And even if Socrates, too,' Plotinus adds, 'may play sometimes, it is by

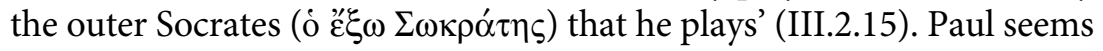

${ }^{14}$ On this notion, see Th. K. Heckel, Der Innere Mensch: Die paulinische Verarbeitung eines platonischen Motivs (Wissenschaftliche Untersuchungen zum Neuen Testament II.53), (Tübingen, 1993); C. Markschies, 'Die platonische Metapher vom "inneren Menschen": Eine Brücke zwischen antiker Philosophie und altchristlicher Theologie', Zeitschrift für Kirchengeschichte 105 (1994), pp. 1-17 (also published in: International Journal of the Classical Tradition 1.3 [1995], pp. 3-18); cf. also 'Innerer Mensch', in: Reallexikon für Antike und Christentum, vol. 18, (Stuttgart, 1998), pp. 266-312; W. Burkert, 'Towards Plato and Paul: The "Inner" Human Being', in: A. Y. Collins (ed.), Ancient and Modern Perspectives on the Bible and Culture. Essays in Honor of Hans Dieter Betz, (Atlanta, GA, 1998), pp. 59-82; and H. D. Betz, 'The Concept of the "Inner Human

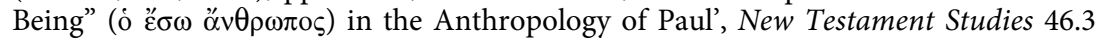
(2000), pp. 315-341. See also van Kooten, Paul's Anthropology in Context, chap. 7.2.2: 'The inner man-the history of a concept', pp. 358-370. 
to employ this notion of the 'inner man' because it is very suitable as a supplement to his criticism of the sophists' outer modus operandi; as a matter of fact, it substantiates his criticism of their position. For him it expresses, in a positive, emphatic, and constructive way, what the Christian message is about.

\section{The Inner Man and His Vices-Paul's Letter to the Romans}

Comparison with Plotinus shows very clearly that Paul has a genuine command of the notion of the inner man and does not use this terminology only superficially. Both Paul and Plotinus appear to dwell on the question of how the inner man relates to virtues and sin. I shall first focus on Plotinus' view on this relation, in order to provide a context in which Paul's reflections on the inner man can be appreciated more clearly. To this end, we shall now first address the question of what Plotinus thinks of the vices which, despite the process of becoming god-like, remain in man. Plotinus devotes much discussion to this specific topic, and his deliberations help us to understand the ins and outs of the notion of the 'inner man'. As we shall see subsequently, it is highly remarkable that this topic is also discussed in Paul, in an extensive passage in the Letter to the Romans, which Paul wrote during his final stay in Corinth.

\section{(a) Plotinus on the Inner Man, Virtues and Sin}

According to Plotinus, the real, proper virtues, which belong to the sphere of intellect, have their seat in the 'true man' (o $\alpha \lambda \eta \theta \dot{\eta} s$

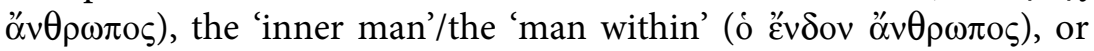
the 'separate soul', as he also calls it - that which transcends the human life and is different from the body and its affections. The other, lesser virtues, however, which result from habit and training, are located in what Plotinus calls 'the joint entity'; this entity is also the seat of the vices (I.1.10). The proper virtues are those which effect the purification of the soul and make it similar to God (I.2.3). Plotinus is interested in the question of how this purification deals with 'passion and desire and all the rest (...), and how far separation from the body is possible'. In his view, the soul 'gets rid of passion as completely as possible, altogether if it can', but the reason why it cannot lies in 'the involun-

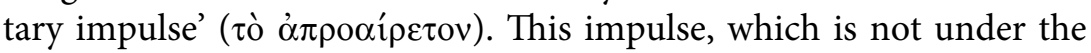


control of will, belongs to something other than the soul, and is small and weak (I.2.5).

On the one hand, Plotinus is optimistic about the soul's possibility to be pure and to achieve its aim of making the irrational part, too, pure. This part profits from the soul's purification,

just as a man living next door to a sage would profit by the sage's neighbourhood, either by becoming like him or by regarding him with such respect as not to dare to do anything of which the good man would not approve (I.2.5).

Insofar as this is the case, the soul is sinless. Yet Plotinus stresses that he is not obsessed, in a negative way, by trying to avoid sin. Rather, his concern, in a positive way, is to become god-like, to be a god. Nevertheless, although Plotinus is optimistic about the soul's potential, he does have to concede that there may still be an element of involuntary impulse in man, which causes him to be not simply god ( $\theta$ còs $\mu$ óvov), but 'a god or spirit who is double' ( $\delta \mathrm{i} \lambda \mathrm{ov} \varsigma)^{15}$ (I.2.6).

As Plotinus says elsewhere, one can argue that the soul is sinless if one assumes the soul to be 'a single completely simple thing and identifies soul and essential soulness'. Yet, the soul is regarded to be sinful if one interweaves with it and adds to it another form of soul (...): so the soul itself becomes compound (...) and is affected as a whole, and it is the compound which sins'. This 'other form of soul' is also called the soul's image ( $\varepsilon$ ' $\delta \omega \lambda \mathrm{ov})$. In order to illustrate his views on the compound soul, Plotinus uses two metaphors, one drawn from Plato, the other from Homer.

The first image relates to the sea-god Glaucus, who is likened to the soul because its real nature is only seen if one knocks off its encrustations (Plato, Republic X 611D-612A). Similarly, the soul's image-the other, added, encrusted form of soul-is abandoned and 'no longer exists when the whole soul is looking to the intelligible world'.

The other image, taken from Homer, concerns the figure of Heracles: 'The poet seems to be separating the image with regard to Heracles when he says that his shade is in Hades, but he himself among the gods' (Homer, Odyssey 11.601-602). Heracles is above inasmuch as he is a contemplative person, but, insofar he is an active person, 'there is

${ }^{15}$ Cf. also 'the other form of soul' in I.1.12 and 'the two souls' in IV.3. Perhaps the notion of a 'double soul' also occurs in The Letter of James, which speaks of dívuos in 1.8 and 4.8 . 
also still a part of him below' (I.1.12; cf. IV.3.27 and VI.4.16). In this respect, Plotinus also speaks of 'the two souls' (IV.3.27). ${ }^{16}$

\section{(b) St Paul on the Inner Man and Sin}

It is highly remarkable that this specific discussion in Plotinus about the relation between the 'inner man' and his vices, which do not belong to the 'inner man' but to something else, and about the 'involuntary impulse' which causes these vices, also seems to occur in Paul's Letter to the Romans. ${ }^{17}$ According to Paul, man is 'fleshly', exported for sale under $\sin (7.14)$. The word 'exported for sale' ( $\pi \varepsilon \pi \rho \alpha \mu \varepsilon \varepsilon v \varsigma)$ is usually used of deporting captives to foreign parts for sale as slaves (LSJ 1394 $\pi \dot{\varepsilon} \rho \vee \eta \mu \mathrm{l})$ and it is difficult to neglect the overtones of deportation from the heavenly fatherland.

Being deported, Paul does not acknowledge his actions as his own, because what he does is not what he wants to do, but what he detests (7.15). He acts against his will, and for this reason, Paul does not regard himself as the one who performs the action, but rather the sin that dwells in him (7.16-17):

${ }^{16}$ For a bibliography on this interpretation of Heracles, see A. H. Armstrong, Plotinus: Ennead IV (Loeb Classical Library), Cambridge, Mass./London, p. 121 note 2. Cf. also R. Lamberton, Homer the Theologian: Neoplatonist Allegorical Reading and the Growth of the Epic Tradition (The Transformation of the Classical Heritage 9), (Berkeley, Calif, 1986), pp. 100-103.

${ }_{17}$ For an analysis of Rom 7 against the background of Graeco-Roman culture and philosophy, see also T. Engberg-Pedersen, 'The Reception of Graeco-Roman Culture in the New Testament: The Case of Romans 7.7-25', in: M. Müller \& H. Tronier (eds), The New Testament as Reception (Journal for the Study of the New Testament Supplement Series 230; Copenhagen International Seminar 11), (London, 2002), pp. 32-57; and R. von Bendemann, 'Die kritische Diastase von Wissen, Wollen und Handeln: Traditionsgeschichtliche Spurensuche eines hellenistischen Topos in Römer 7', Zeitschrift für die Neutestamentliche Wissenschaft und die Kunde der Älteren Kirche 95 (2004), pp. 35-63, esp. pp. 55-61 on Epictetus. Von Bendemann, however, scarcely mentions the 'inner man' (see briefly pp. 52, 59, 61-62) and does not refer to Plotinus' discussion of the inner man and the involuntary impulse within man. An excellent approach is undertaken by E. Wasserman, 'The Death of the Soul in Romans 7: Revisiting Paul's Anthropology in Light of Hellenistic Moral Psychology', Journal of Biblical Literature 126 (2007), pp. 793-816. Wasserman argues that 'Romans 7 appropriates a Platonic discourse about the nature of the soul and describes what happens to its reasoning part when the bad passions and appetites get the upper hand' (Wasserman, 'The Death of the Soul', 800). See also E. Wasserman, The Death of the Soul in Romans 7: Sin, Death, and the Law in Light of Hellenistic Moral Psychology (Wissenschaftliche Untersuchungen zum Neuen Testament II.256), (Tübingen, 2008). 
For I know that nothing good dwells within me, that is, in my flesh. I can will what is right, but I cannot do it. For I do not do the good I want, but the evil I do not want is what I do. Now if I do what I do not want, it is no longer I that do it, but sin that dwells within me (7.18-20).

These ideas clearly share Plotinus' insistence that it is the compound soul which sins, and not the inner man; if this compound soul does sin, it does so involuntarily. Like Plotinus, Paul contrasts the 'flesh', his 'unspiritual self', with the 'inner man', which is regarded as sinless:

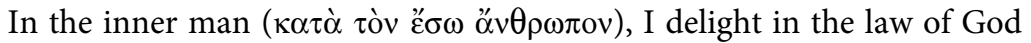

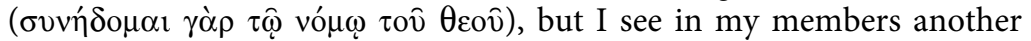
law at war with the law of my mind (vov̂s), making me captive to the law of sin that dwells in my members. (...) (...) So then, with my mind (vov̂) I am a slave to the law of God, but with my flesh I am a slave to the law of $\sin (7.22-23,25 b)$.

Although Paul puts it in a more dramatic fashion, he and Plotinus basically seem to agree that the true self, the inner man, is sinless and rejoices in God's law. This compliance with divine law is also brought out in Plotinus. According to him,

when a man (...) comes to the divine, it stands over him and sees to it that he is man; that is, that he lives by the law (vónos) of providence,

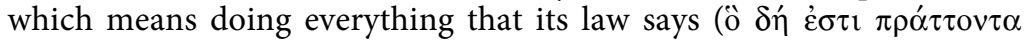

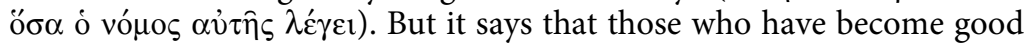
shall have a good life, now, and laid up for them hereafter as well, and the wicked the opposite (III.2.9).

There is fundamental agreement between Plotinus and Paul about the ethical purpose of the notion of the 'inner man', and of the real possibility that man rejoices in God's law, the law of providence. To acknowledge that there is still an involuntary impulse operative in man is, for them, not to justify unethical conduct. Quite the opposite, since the driving force behind the notion of 'inner man' is the idea that man should be transformed into God's image and become as god-like as pos-

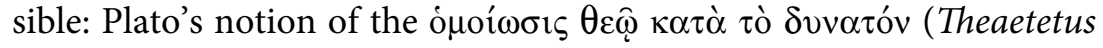
176B). ${ }^{18}$ The Lutheran interpretation of Paul's view on man as 'simul

18 On this notion, see D. Sedley, 'The Ideal of Godlikeness', in: G. Fine (ed.), Plato, vol. 2: Ethics, Politics, Religion, and the Soul (Oxford Readings in Philosophy), (Oxford, 1999), chap. 14, pp. 309-328; J. Annas, Platonic Ethics, Old and New (Cornell Studies in Classical Philology 57), (Ithaca, N.Y., 1999), chap. 3: 'Becoming Like Gods: Ethics, Human Nature, and the Divine', pp. 52-71; and van Kooten, Paul's Anthropology in Context, chap. 2.2: "The "image of God" and "being made like God": The traditions of homoiōsis 
iustus et peccator', as if this were a steady, static mixture, leads to a severe misunderstanding of Paul's anthropology. ${ }^{19}$ Paul and Plotinus regard the 'inner man' as progressive in nature: 'The soul gets rid of passions as completely as possible, altogether if it can, but if it cannot, at least it does not share its emotional excitement' (I.2.5); 'we are being transformed into God's image with ever-increasing glory' (2 Cor 3.18), and 'the inner man is renewed day by day' (4.16).

Paul's deliberations in chapter 7 of his Letter to the Romans about the relation between the 'inner man' and the vices which involuntarily remain in man show that he is indeed very well acquainted with the Platonic notion of the 'inner man'. Later on in this letter, Paul's line of thought again closely resembles the ideas already expressed in 2 Cor. Man is destined to acquire the same form as the image of God's Son, so

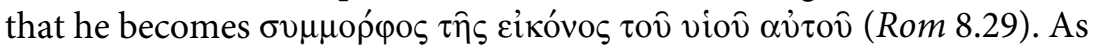
is the case in 2 Cor, this form ( $\mu о \rho \varphi \eta)$ is the result of his transformation. This transformation is effected by the renewing of one's mind, Paul explains in Rom 12. There, Paul exhorts his readers to be transformed

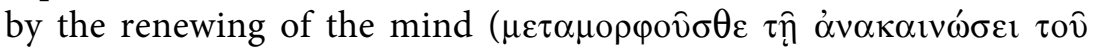
voós), so that they can examine the will of God, which-as in Plato's Euthyphro-is not arbitrary, but is characterized as that which is good,

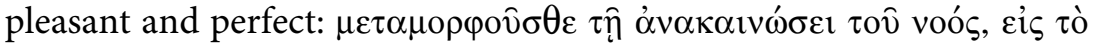

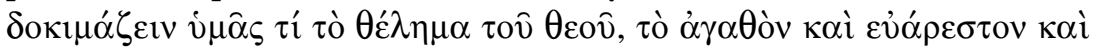
$\tau \varepsilon \dot{\lambda} \varepsilon 10 v$ (12.2).

According to Paul, this inward transformation is in fact-as we have

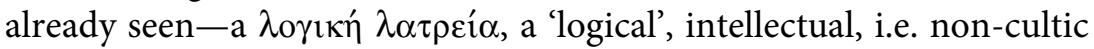
worship of God (12.1). ${ }^{20}$ That this transformation is effected within

theōi in Greek philosophy from Plato to Plotinus', pp. 124-181. On its importance in Middle Platonism, contemporarily with Paul, see J. Dillon, The Middle Platonists: A Study of Platonism 80 B.C. to A.D. 220-Revised edition with new afterword, London, 1996 $\left(1977^{1}\right)$, Index, s.v. 'Likeness to God'.

${ }_{19}$ For this Lutheran interpretation, see H. Lichtenberger, Das Ich Adams und das Ich der Menschheit: Studien zum Menschenbild in Römer 7 (Wissenschaftliche Untersuchungen zum Neuen Testament 164), (Tübingen, 2004), chap. 3.3, pp. 24-28, esp. 27.

${ }^{20}$ For Paul's polemical purpose behind this passage, and behind the beginning of his letter in Rom 1, see G. H. van Kooten, 'Pagan and Jewish Monotheism according to Varro, Plutarch and St Paul: The Aniconic, Monotheistic Beginnings of Rome's Pagan Cult-Romans 1:19-25 in a Roman Context', in: A. Hilhorst, É. Puech \& E. Tigchelaar (eds), Flores Florentino: Dead Sea Scrolls and Other Early Jewish Studies in Honour of Florentino García Martínez (Supplements to the Journal for the Study of Judaism 122), (Leiden/Boston, 2007), pp. 633-651 (= van Kooten, Paul's Anthropology in Context, chap. 7.1, pp. 343-356). 
the mind (vovs) is consistent with Paul's view, expressed earlier in the letter, that the 'inner man' is located within the mind. This follows

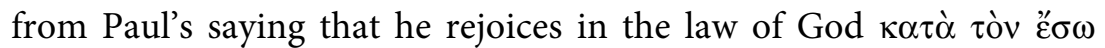

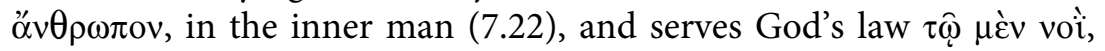
with the mind (7.25).

\section{Concluding Observations}

The passages from the Pauline epistles adduced above seem to demon-

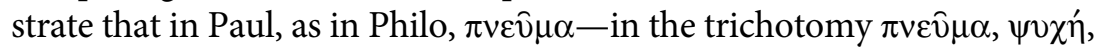
and $\sigma \hat{\omega} \mu \alpha-$ is identified with vov̂s. Philo's and Paul's anthropology of tripartite man is very similar. One might ask whether there is in fact any difference between their anthropology and pagan trichotomous counterparts. Inasmuch as Philo and Paul refer to the highest part of man not only as vov̧ but preferably (on account of their exegesis of Gen 2.7) as $\pi v \varepsilon v \hat{\mu \alpha} \alpha$, one might also suggest that they stress the identical, pneumatic nature of God and man in a far more egalitarian and accessible way than is the case in the Greek equivalent anthropology. In order to experience fellowship with God, man does not have to improve the intellectual abilities of his vov̂ but is connected through the $\pi v \varepsilon \hat{\mu} \mu \alpha$. In Plutarch, as John Dillon explains, the highest class of people, who possess vov $\varsigma$, is rather restricted: 'Intellect [vov̂s] thus becomes something rather special, not readily accessible to the mass of humankind. ${ }^{21}$ Both Philo and Paul make transition from vov̂ to Festugière: 'Du vov̂ऽ au $\pi v \varepsilon \hat{v} \mu \alpha$, voilà toute la différence, ce qui (...) distingue spécifiquement le christianisme. ${ }^{22}$ More than in pagan philosophy, participation in God himself is open to all:

Notre âme est déjà son $\pi v \varepsilon \hat{\mu} \mu \alpha$. Tout naturellement, dès lors, elle devient

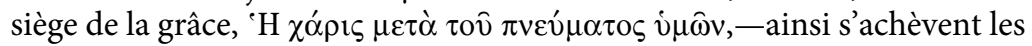
lettres aux Galates, VI, 18, aux Philippiens IV, 23, à Philémon 25,-habitacle de l' ó $\gamma$ iov $\pi v \varepsilon \hat{\mu} \mu \alpha$, du saint-Esprit. (...) Ainsi, grâce à Paul, grâce au christianisme, ce qu'il y eut de meilleur dans l'âme païenne trouve enfin son vrai sens. (...) L'intelligence devient esprit. ${ }^{23}$

${ }^{21}$ Dillon, 'Plutarch and the Separable Intellect', p. 44.

${ }^{22}$ Festugière, L'idéal religieux des grecs et l'évangile, p. 217.

${ }^{23}$ Festugière, L'idéal religieux des grecs et l'évangile, pp. 219-220. 
The free accessibility of this pneumatic identity is an aspect of Paul's 'Adam Christology', as James Dunn calls it. ${ }^{24}$ By participating in Christ's death and resurrection in baptism (Rom 6.3-11), the human identity starts to fuse with that of Christ, the second Adam, the second man who, in contrast to the first man, is from heaven. Whereas man still bears the image of the first, earthly Adam (1 Cor 15.49), Christians increasingly bear the image of the heavenly man and are increasingly transformed into his likeness ( 2 Cor 3.18). In this way their $\pi v \varepsilon v \hat{\mu \alpha}$ is restored and they again turn into trichotomous human beings, pneumatikoi. For this reason, they can boldly claim to possess the vov $\varsigma$ of Christ (1 Cor 2.15-16), the vov̂ of the heavenly, archetypal man. Whereas for Plutarch the highest class of human beings, the possessors of vov $\varsigma$, is sparsely populated, for Paul, this possession is within reach for all Christians. The more they share in the $\pi v \varepsilon v \hat{\mu} \alpha$ and $v 0 \hat{v}$, , the more their outer man decreases and their inner man, the है $\sigma \omega$ ö $\theta \theta \rho \omega \pi \mathrm{o}$, develops. Despite this significant difference in emphasis, at the same time Paul's anthropology appears to be highly Greek-philosophical in nature; it entails the trichotomous differentiation between $\pi v \varepsilon \hat{\mu} \mu \alpha$ / vovิs, $\psi v \chi \eta$, and $\sigma \hat{\omega} \mu \alpha / \sigma \alpha ́ \rho \xi$, and builds upon reflections on the inner man.

${ }^{24}$ See J. D. G. Dunn, The Theology of Paul the Apostle, (Edinburgh, 1998), chaps 4, 8.6, 10.2. The principle passages containing Adam Christology are Rom 5.12-6.11; 1 Cor 15.20-28; 1 Cor 15.45-49. 